This is an electronic copy of an article published in:

Margolis, R. (2009). Culture in motion: Yiddish in Canadian Jewish life. Journal of Religion and Popular Culture, 21

(spec. ed.). Available online at: http://www.usask.ca/relst/jrpc/art\%28se\%29-Yiddish.html

\title{
Culture in Motion: Yiddish in Canadian Jewish Life
}

\author{
Rebecca Margolis \\ University of Ottawa
}

\begin{abstract}
Résumé
Le vingtième siècle a vu la transformation du Yiddish au Canada: la langue s'est déplacée d'un vernaculaire immigrant, à une langue de haute culture, à une langue d'héritage et à une composante de la culture populaire juive. Cette transformation correspond à un changement de sa vie institutionnelle, notamment de la publication, la littérature, l'éducation et le théâtre et la musique. L'immigration de masse de dizaines de milliers de juifs Yiddishophones Europe de l'est au début du vingtième siècle a rendu la langue une force significative dans les centres juifs au Canada. Depuis l'Holocauste, le Canada Yiddish a montré la vitalité face à l'usure globale, tant dans la culture Yiddish séculaire modern que dans les communautés Haredi (Ultra Orthodoxes). Ses mécanismes primaires pour la transmission sont centrés sur la performance aussi bien que la traduction.
\end{abstract}

\begin{abstract}
The past century has transformed Yiddish in Canada: it has moved from an immigrant vernacular, to a language of high culture, to a heritage language and component of Jewish popular culture. These changes are reflected in shifts in its institutional life, notably in publishing, literature, education, and theatre and music. The mass immigration of tens of thousands of Yiddish-speaking Eastern European Jews during the early twentieth century rendered the language a significant force in Jewish centres across Canada. In the decades since the Holocaust, Yiddish Canada has shown vitality in the face of global attrition, both in modern secular Yiddish culture and in Haredi (Ultra Orthodox) communities. Its primary mechanisms for transmission are centred on performance as well as translation.
\end{abstract}

\section{Introduction}

[1] In an online search of "Yiddish Canada," what comes up most often today are references to popular works on the language and culture (Yiddish World of Michael Wex), performances with Yiddish content (Ashkenaz Festival, Dora Wasserman Yiddish Theatre), and Yiddish library collections (The Joe Fishstein Collection of Yiddish Poetry). While this cursory search offers a far from exhaustive picture of the current state of Yiddish in Canada, it does provide insight into new trends associated with the language: the mass dissemination of a popular culture based in 
Yiddish and its increasing presence in the realms of performance, translation and scholarship.

Less evident are the uses of Yiddish within Canada's insular Haredi (Ultra Orthodox) communities.

[2] This study discusses the multivalent face of Yiddish within Canadian life. It focuses on two ends of the Jewish spectrum: the inclusive milieu of secular Yiddish culture, and the exclusive arena of the Haredi world. It posits an inverse relationship between the vitality of Yiddish as a vernacular, and Canada's status as centre of Yiddish culture. That is, before 1950, when Yiddish functioned as the dominant spoken language for the nation's Jews, Canada's status was as a minor centre of Yiddish culture, in particular in the realms of literature, publishing, and theatre. At the same time, the community established a strong institutional base to support Yiddish education. After 1950, despite the ongoing decline of Yiddish as spoken language in the mainstream Jewish community, Canada emerged as a major centre of Yiddish culture, in particular in the areas of theatre and literature, with an ongoing commitment to Yiddish education. While the language has forfeited its status as the lingua franca of Canadian Jews, Yiddish is evincing new mechanisms of popular transmission, notably through performance and translation. Meanwhile the locus of Yiddish as a vernacular of daily use is increasingly characterizing Hasidic society. ${ }^{1}$

\section{Background: The Evolution of Yiddish}

[3] The thousand year-old language of Ashkenazi civilization, ${ }^{2}$ Yiddish is one of dozens of tongues written in Hebrew characters to emerge among Jewish diaspora populations worldwide. Scholars place the origins of Yiddish in the Rhine Valley and characterize it as a "fusion language" comprised of Germanic, loshn-koydesh (holy tongue, pre-modern Hebrew and 
Aramaic), elements of Judeo-Romance languages, and, with eastward migration, Slavic components (Harshav 1990; Jacobs 2005; Katz 1987; Kerler 1999; Weinreich 1970). Three features characterized Yiddish in pre-modern Ashkenazi civilization. First, as the day-to-day spoken language of a widely dispersed minority, Yiddish evolved in a "universal coterritoriality with other languages," and is characterized by a long history of reciprocal influence with surrounding cultures (Jacobs 2005, 264). Second, Yiddish functioned within a traditional system of internal Jewish bilingualism, or diglossia, where loshn-koydesh occupied "high" functions as the language of prayer and sacred text, and Yiddish filled complementary "low" functions as universal vernacular, with some overlap (see Harshav 1990). Third, until the modern period, Yiddish lacked both political and social status.

[4] The Jewish encounter with modernity some two centuries ago triggered a profound and total transformation in a "modern Jewish revolution" (Harshav 1990, 119-138). European Jewry was faced with new choices: a religious spectrum ranging from extreme observance and rejection of modernity through secular identity; diverse political affiliations, in particular leftwing and nationalist movements; and a variety of language choices, from the adoption of non-Jewish languages such as German or Russian to ventures to revive Hebrew or elevate Yiddish as the core/cores of Jewish identity (Hebraisim and Yiddishism). Emancipation in Western and Central Europe prompted Jewish acculturation into mainstream society and a concomitant decline of Yiddish. However, from the mid-nineteenth century until the 1917 Revolution, the majority of world Jewry found itself under Tsarist rule, facing growing anti-Jewish legislation that included restrictions on residence and livelihood. Forced into the Pale of Settlement, most Jews lived in shtetlekh (small market towns; sing. shtetl), where, alongside traditional Jewish religious observance and folkways, Yiddish remained the dominant Jewish language into the twentieth 
century. Thus, in the 1897 Imperial Census, 98\% of Russian Jews declared Yiddish their native language. In the steady erosion of traditional eastern European Jewish society, modern Yiddish culture emerged from the pragmatic efforts of maskilim (modernizers) and political activists to reach the Jewish masses, despite initial contempt for the "zhargon (jargon)" (Estraikh 2005, Fishman 2005). The period brought an explosion of secular Yiddish culture, with the emergence of modern Yiddish literature in the 1860s, popular theatre in the 1870s, and a popular Yiddish press by the end of the century finding a captive audience of millions and a mass consumer base. This secular culture paralleled the emergence of Ladino (Judeo-Spanish) culture that evolved among Sephardi ${ }^{3}$ Jews in Southeastern Europe, but on a far greater scale (see Stein 2006). [5] By the turn of the twentieth century, Yiddish was filling new roles. Increasing numbers of Jewish nationalists and other cultural activists were rallying for recognition of Yiddish as language in its own right as a key to Jewish revitalization and continuity. The ideological movement known as Yiddishism was cemented in the wake of the watershed 1908 Czernowitz Conference, which brought together influential intellectuals in a public and symbolic legitimization of Yiddish as "a language of the Jewish people" and spurred the expansion of "high" culture functions for Yiddish: education, literature and scholarship (see Fishman 1981, Goldsmith 1987). Until the eve of the Holocaust, Yiddish remained the dominant lingua franca of a religiously and socially diverse Jewish community in flux, with an estimated 11 million speakers worldwide, or $75 \%$ of world Jewry. Meanwhile, the mass emigration of over two million Russian Jews between 1880 and 1920, prompted by anti-Semitic persecution and pauperization, transferred Yiddish language and culture to new shores, with its epicentre in New York. Yiddish thus came into its own between the world wars in cities on both sides of the Atlantic: state-sponsored Yiddish language planning and cultural production in Kiev; elite 
culture and scholarship in Vilne (Vilnius); major daily newspapers with hundreds of thousands of readers in Warsaw; a dozen Yiddish theatres on New York's Second Avenue, and so on. For a brief flash in its long history, Yiddish comprised a complete culture that spanned the ideological spectrum and included modern schools, youth groups, scholarly institutions and university programs, libraries, newspapers and journals, theatre, belles-lettres, world literature in translation, and political activity.

[6] In the last hundred years, Yiddish has shifted from the shared language of millions of Ashkenazi Jews worldwide to one that has increasingly been branded as "dying." The Holocaust's annihilation of roughly half of the world's Yiddish speakers and its decimation of the traditional Yiddish heartland in Europe has resulted in a fundamental geographic reorientation of the map of "Yiddishland"- defined by Jeffrey Shandler as the "the virtual locus" of Yiddish use $(2006,33)$ — to immigrant centres, in particular America. However, even before the Holocaust, upwardly mobile Jews worldwide were opting for languages other than Yiddish, notably English, Polish and Russian. This steady erosion away of Yiddish language and its culture was further exacerbated by the dissolution of Soviet state-sponsored Yiddish culture under Stalin and the suppression of Yiddish in the newly created State of Israel.

[7] With this radical reconfiguration of the Yiddish diaspora, the functions of the language have changed dramatically. Janet Hadda identifies a new polarization in post-Holocaust Yiddish culture: one end of the spectrum is occupied by the inward-oriented Yiddish culture of Haredim, where Yiddish serves to maintain boundaries from the outside, secular world; the other is taken up by "neo-Ashkenaz," a "wildly inclusive" culture based in Yiddish that is widely accessible and transcends ethnic boundaries $(2002,15)$. Shandler's concept of "postvernacular" Yiddish culture posits new symbolic meanings assigned to the language across the spectrum of post- 
Holocaust "Yiddishland" (2006). A recurring term in the contemporary discourse of Yiddish is "heritage," which Barbara Kirshenblatt-Gimblett has defined as "a mode of cultural production that gives the disappearing and gone a second life" $(2002,133)$. While these models refract Yiddish through specifically American lenses, two underlying tenets hold true for the Canadian context: (1) the meaning of Yiddish has changed dramatically in the last hundred years, and (2) anyone who engages with the language today does so deliberately, regardless of one's religious orientation or background.

\section{Yiddish Canada}

[8] With significantly different experiences of immigration and acculturation from the neighbouring United States (Cohen, Steve 1993; Tulchinsky 1992; Weinfeld 2001), Canada has demonstrated long-term Yiddish vitality. Several factors account for this resilience: relatively later dates of mass immigration combined with stronger nationalist tendencies; the absence of a constitutionally enshrined separation of church and state and accompanying universal public school system to promote Canadianization; Jewish marginalization and a general lack of a unifying Canadian nationalism to promote assimilation (Orenstein 1981; Ravitch 1963). In the final analysis, Canada shares more in common with other Yiddish immigrant centres such as Mexico, Argentina or Melbourne.

[9] As the primary destination for the 125,000 Jews that settled in Canada during the mass migration between 1905 and 1920, Montreal served as Canada's Yiddish centre, followed by Toronto and Winnipeg. As part of the first significant non-Christian group in Canada, the waves of immigrants that deluged a tiny pre-existing anglicized Jewish community were conspicuous in both language and religious and political loyalties. In the province of Quebec, where the Jewish 
community was sandwiched between the French-Catholic and English-Protestant charter groups, Yiddish functioned as Montreal's third language, both officially and unofficially (see Harris 2006). Marginalized by both dominant groups, immigrant Jews of all stripes joined an emerging venture to build a religious, social, and cultural infrastructure, with Yiddish as the common language. For these Jewish activists, Montreal formed the site of what David Roskies has termed a "utopian venture" where a group of "lay intellectuals" forged a maximalist, future-oriented culture of yiddishkayt ${ }^{4}$ as the basis for Jewish continuity (1990). Ideology was translated into active community building, and active community building into cultural preservation, whether the mechanisms were secular Yiddish culture, Orthodox Judaism or Zionism. The common denominator was Yiddish, as a means or an end, or both.

[10] This Yiddish "utopia" remained a vital force for decades after the Holocaust, with the community's high degree of institutional completeness promoting an intergenerational transmission of Jewish ethnic identity (Rosenberg and Jedwab 1992). Yiddish day schools allowed the children of immigrants to bridge the worlds of English and Yiddish, and for their grandchildren to gain an awareness and appreciation of Yiddish culture. Moreover, Canada experienced a Yiddish revitalization through the arrival of large numbers of Holocaust survivors in the late 1940s and 1950s. Despite the country's dismal record of Jewish immigration between 1933 and 1948 (Abella and Troper 1983), Montreal became home to the world's third-largest concentration of Holocaust survivors, most of them Yiddish speakers. Among this group were Haredi Jews, who have transplanted to Canada a culture of traditional Jewish diglossia combined with a rejection of modern, secular society.

[11] While it has become increasingly rare to find Yiddish experienced as a complete culture, Canada — and Montreal in particular—continues to show a high degree maintenance of Yiddish 
as a daily spoken language. At the same time, new expressions of Yiddish culture are evolving across the country. In the secular realm in particular, the transformation of Yiddish Canada in the last decades has been profound. Visitors to today's Yiddish cultural scene such as a music festival will find the crowd conversing in English and performers who might be singing in Yiddish but addressing the crowd in English with Yiddish terms such as "nu" and "oy" thrown

in. Familiar Montreal haunts where Yiddish was spoken in the old Jewish neighbourhood along “the Main” (Saint Lawrence Blvd St.-Laurent), including the headquarters of the Socialist Arbeter Ring (Workmen's Circle) or the offices of the daily newspaper, the Keneder Adler (Canadian Jewish Eagle), have yielded to Jewish-style restaurants and up-scale clothing stores. Those in search of spoken Yiddish will increasingly find it used not as shared vernacular for the Jewish community as a whole but as an insider language in Hasidic enclaves. In short, Yiddish as a complete culture has given way to entirely different visions of Yiddish in Canada.

\section{Canadian Yiddish Demographics}

[12] Yiddish has shown tremendous resilience in Canada. During the first half of the twentieth century, even as new arrivals integrated and adopted English, successive waves of immigrants bolstered the population of Yiddish-speaking Jews. Moreover, a well-developed cultural life supported its ongoing role as the collective language of the community. In 1931, 99\% of Montreal Jews — who made up just six percent of the city's total population-declared Yiddish Mother Tongue (YMT). ${ }^{5}$ As a point of comparison, Polish census data for the same year indicate $91 \%$ YMT for the Jews of Warsaw, where Jews made up about a third of the total population (Nathan 2002, 163). Meanwhile, in 1910, some 50\% of Jews in the United States 
declared YMT, a statistic that corresponds roughly to the numbers for Canadian Jews after World War II. ${ }^{6}$

[13] However, these statistics mask the ongoing pervasiveness of Jewish linguistic acculturation in Canada. While most of the Jewish immigrants who settled in Canada between 1890 and 1950 claimed Yiddish as mother tongue, they were also adopting English as their lingua franca. A shift away from Yiddish as the lingua franca of the Canadian Jewish community was underway by the 1920s, when the tightening of immigration laws reduced the arrival of new Yiddishspeaking Jews to a trickle until the late 1940s. At the same time, the second generation was steadily acculturating away from Yiddish. Canadian census statistics of YMT and English Mother Tongue (EMT) among Canadian Jews highlight these quantitative changes (Rosenberg 1939, 257):

\begin{tabular}{|l|l|l|l|l|}
\hline Year & 1921 & 1931 & 1941 & 1951 \\
\hline Total Jews & 126,000 & 155,700 & 168,000 & 204,800 \\
\hline YMT & $91 \%$ & $96 \%$ & $76 \%$ & $43 \%$ \\
\hline
\end{tabular}

[14] The pattern in Canada was slow but steady Anglicization. Between 1931 and 1951, the number of Jews declaring English as mother tongue increased from $2 \%$ to $51 \%$. Meanwhile, a vast majority of Canadian Jews had some level of English by 1931, with just 3\% of the population declaring themselves unable to speak the language (Rosenberg 1939, 255). Even with the influx of Yiddish-speaking survivors of the Holocaust to bolster the community, the Canadian-born population was integrating into the English milieu. YMT dropped to $32 \%$ in 1961 and $11 \%$ in 1981, when Yiddish was declared language of the home for less than $4 \%$ of Canada's 296,000 Jews (Davids 1993). Moreover, since the 1960s Canada's Jewish community 
has also come to include significant numbers of non-Ashkenazi groups with no historic connection to Yiddish.

[15] Even without the rupture of the Holocaust, wider trends appear to point towards an inevitable global decline of Yiddish as shared vernacular. Acculturation was at work as upwardly mobile Jews opted for the languages of the dominant culture in which they lived, be it Polish, Russian or English. Thus, while almost 80\% of Polish Jews declared YMT in the 1931 census, Yiddish use in areas such as education and reading were on the decline, in particular among the higher economic echelons (Nathan Cohen 2002, 172). In the wake of both assimilation and severe state repression in the Soviet Union, YMT among Russian Jews declined to $41 \%$ in 1939, and it continued to fall steadily (Estraikh 1999). In the end, the same forces that created modern Jewish culture-the quest for new expressions of identification among the Jewish masses— have ultimately led to its corrosion.

[16] Fast-forward to today, when the Canadian census reveals that YMT has declined from 19,295 in 2001 to 17,255 in 2006, and the number of Yiddish speakers has declined from 37,010 to 27,605. Meanwhile, Modern Hebrew—the official language of the State of Israel and a core component of mainstream Jewish education for over half a century-is growing in use among Canadians, with 67,390 speakers. The responses to these trends are revealing. An article in The Canadian Jewish News centres on the fact that, for the first time, Hebrew has eclipsed Yiddish as mother tongue for Jews in Canada, with Jack Jedwab, executive director of the Association for Canadian Studies (ACS), referring to the statistics as "shocking but not surprising." Jedwab praises the Jewish schools in Montreal and Toronto that continue to teach Yiddish, but asserts that the future of the language is "simply not on the community agenda" and is contingent on personal connections, with "the current state of Yiddish is part of the shifting patterns of Jewish 
identity." He predicts: "Yiddish will not be an important part of Jewish identity except at some sort of folkloric level, except maybe in Chassidic communities. The critical mass is declining" (Lazarus 2008). In contrast, an article published in the Montreal Gazette titled "Language of Past Sets Hasidim Apart Today" debunks the notion that Yiddish is on the decline because of growing numbers of Ultra Orthodox speakers (Heinrich 2008).

\section{Hasidim and Yiddish}

[17] Today, Hasidim increasingly comprise the world's Yiddish speakers, a far cry from a century ago when Yiddish was the lingua franca of Jews from Eastern Europe across the religious spectrum. Hasidism evolved from an $18^{\text {th }}$ century populist Jewish mystical movement in Eastern Europe into a conglomeration of sects characterized by their strict religious observance, allegiance to charismatic rabbis known as rebbes, and rejection of modernity. With the locus of Hasidic life destroyed in the Holocaust, Hasidim today form a transnational ethnic community that espouses segregation from mainstream society and continuity with premodern Jewish Eastern Europe, in particular in dress and language. They maintain the traditional diglossic pattern of Yiddish as insider, oral language and loshn-koydesh as public language. At the same time, Yiddish functions as the ultimate linguistic group marker (Baumel 2003, 105). For many Hassidic communities, Yiddish has shifted from an immigrant language to an ethnic language that functions as a manifestation of positive values and a "one-way barrier" to the secular world (Isaacs 1998, 14-15). Active resistance of mainstream culture combined with a comprehensive school system work in tandem to promote Yiddish as a core community language (Glinert 1999, 49). 
[18] The Montreal region houses the second largest population of Hasidim in North America after New York. Some ten sects linked to different places of origin in Poland, Hungary, Romania, Czechoslovakia and Russia comprise a rapidly growing community: estimates in the last decade vary widely from 8,000 (Deshaies et. al. 1997) to 20,000 (Châteauvert and DupuisDéri 2004, 63). While most Hasidim settled in Canada after 1940, a Hasidic presence dates to the 1880s; the interwar period marked the establishment of a community infrastructure (Lapidus 2004; Robinson 2007). Largely survivors of the Holocaust and their descendants, Montreal's Hasidim live in tightly knit communities that minimize contact with the outside. The extreme example is Kiryas Tash (Tosh), an insulated Hasidic community established in the nearby town of Boisbriand in 1963 (Kiryas Tash; Hatzolah Kiryas Tosh). Aside from the Lubavitch sect, which promotes outreach to non-Haredi Jews and thus employs other vernaculars, Yiddish is used among Hasidim to maintain boundaries and a distinctive identity in community efforts at "insulating their members from the secular influence of the host culture" (Shaffir 1995, 77). Hasidim speak Yiddish day-to-day at home, in the community and with their children. This helps to explain the relative gap in Yiddish use between Montreal and Toronto, which does not have a major Hasidic presence:

\begin{tabular}{|l|l|l|l|}
\hline & Canada & Montreal & Toronto \\
\hline Jewish population & 315,000 & 71,380 & 141,685 \\
\hline Yiddish speakers, all ages & 27,605 & 13,515 & 10,345 \\
\hline Yiddish speakers, under age 5 & 1,345 & 1,180 & 140 \\
\hline Yiddish speakers, over age 75 & 9,305 & 3,345 & 4,390 \\
\hline
\end{tabular}

(Statistics Canada 2006) 
Despite having more than double its current Jewish population, Toronto has significantly fewer Yiddish speakers than Montreal, in particular among the young.

\section{Canadian Yiddish Culture Before 1950}

[19] Canadian Yiddish institutional life dates to the turn of the twentieth century. It forms part of a rapid expansion of modern Yiddish culture in Eastern Europe and its immigrant communities where major centres such as Warsaw, Vilna and New York fed a network of minor centres globally. The international traffic of newspapers, specialty periodicals, books, plays, ideas and key personalities brought a rich cross-fertilization of Yiddish culture. Core institutions of Yiddish culture—the popular press, libraries, schools, and theatre—developed in tandem globally, motivated in part by ideological convictions about modern cultural revitalization via Yiddish and in part by pragmatic reasons: the familiar and widely spoken language represented the best way to reach the Yiddish masses.

\section{Yiddish Literature and Publishing}

[20] In the matrix of modern Yiddish culture, literature took centre stage. Canada was home to a core group of writers who published in newspapers and periodicals, produced journals, organized literary activity and hosted visiting literary figures. However, Canadian Yiddish literature came of age relatively late in the 1920s and never produced a particular school of writers like New York's modernist Di Yunge (Young Ones) or the avant-garde Inzikhistn (Introspectivists). With both contemporaneous English and French language Canadian letters in their infancies, Yiddish writers looked to European and American models. Among the distinguishing features of Canadian Yiddish literature are depictions of the local landscape combined with an ongoing 
attachment to the Old World (Fuerstenberg 1984; Orenstein 1981): as writer Chava Rosenfarb has put it, in comparison with his or her American counterpart, the Canadian Yiddish writer "never completely unpacked his [sic] Eastern European valises" (2004, 12). Although most Canadian writers remained minor figures on the world stage, they understood themselves as part of a global movement of Yiddish letters and participated in wider trends. A partial list of the group, which spans the Jewish spectrum from secular through observant, includes: Montreal writers and poets N.Y. Gotlib, Ida Maza, Shapse Perl, Yudl Rosenberg, Esther Segal, J.I. Segal, M.M. Shaffir, A. Sh. Shkonikov, Sholem Shtern; Toronto poets Benyomin Katz, Sh. Nepom and Yudika (Yudis Tsik), Yaakov Zipper and Yehuda Zlotnik; Winnipeg writers and poets Mordkhe Miller and Louis Rosenberg; Montreal Yiddish critics H.M. Caiserman and Israel Rabinovitch; and historian B. G. Sack. Before 1950, the chief site for publication was local Yiddish newspapers.

[21] The most influential branch of modern Yiddish culture was the popular press, which emerged in the last decades of the nineteenth century in both Eastern Europe and its immigrant centres. A proliferation of Yiddish dailies, weeklies and specialty journals were essential to the emergence of a culture of Yiddish literacy by creating both writers and readers where previously there had been none. Jewish periodicals were more often than not divided along ideological lines, and a majority were short-lived. They shared dual goals: to educate the Yiddish masses and to propagate ideology, be it a commitment to leftist politics or high art (see Cohen and Nathan 2007; Margolis 2009; Michels 2003; Stein 2004).

[22] The primary venue for Yiddish letters before World War II remained the Yiddish press. It was mass dailies, weeklies, speciality journals and miscellanies—not books—-that formed the site of new developments in modern Jewish culture in the late nineteenth and early twentieth 
centuries (Mintz 1995, 1). Although books have been revered as cultural objects within modern Yiddish culture (see the Joe Fishstein Collection of Yiddish Poetry), they enjoyed a limited consumer base. This is, in part, because Yiddish book publishing shared "the permanent economic crisis common to all Yiddish cultural institutions" (Steinlauf 2003, 84): a chronic lack of funds. Modern Yiddish culture in both Europe and its offshoots largely remained the purview of the lower socioeconomic classes, which imbued it with a formidable vitality as well as built-in economic obstacles. In short, the Jewish middle classes who were acculturating into higher status languages could afford books, while Yiddish working class readers could not. The market for elite literature was even more constrained. Moreover, the height of Yiddish culture coincided with the onset of the Depression and growing economic crisis on the world stage. Without the commercial publishing houses of Poland (Kellman 2003) or state support of the Soviet Union (Shneer 2004), minor centres such as Canada lacked a viable Yiddish book market. [23] The development of a Canadian Yiddish press was initially impeded by a smaller local readership and the easy importation of American newspapers from nearby New York. Lasting newspapers and journals came into existence in Canada the years leading up to World War I (see Hill 2006). After numerous failed attempts, lasting popular newspapers came into existence: Montreal's Keneder Adler/Canadian Jewish Eagle (founded in 1907), appeared as a daily beginning in 1908; Winnipeg's Dos yidishe vort/The Israelite Press (founded in 1910 as Der kurier, The Courrier) and Toronto's Der yidisher zhurnal/The Daily Hebrew Journal (founded in 1912) appeared as weeklies from the 'teens. These publications functioned both to acclimatize an immigrant readership to Canadian life and to promote Yiddish culture. Moderate and inclusive, their pages featured virtually every Yiddish writer in the country, from radical 
anarchists to Orthodox rabbis. Meanwhile, a variety of speciality publications catered to the interests of specific local readerships, including some twenty literary journals (Margolis 2009).

\section{Yiddish Education}

[24] Education formed a core component of modern Yiddish culture. "A youth culture revolving around autodidacticism" that flourished in the Yiddish world spurred the mushrooming of libraries and other forums for organized adult education (Kellman 2003, 215). Chapters of leftwing organizations such as the labour Zionist Poale Zion and Socialist Arbeter Ring promoted Yiddish cultural activity across Canada (Belkin 1956, 1999; Usiskin 1977). The Yiddish libraries that sprang up across Canada - whether in remote rural settlements or major urban centres_-served dual functions: to edify and entertain new settlers and to build a sense of community, whether real or imagined. These early institutions generally began as small, mobile collections of Yiddish books that circulated among likeminded individuals; for example, a library formed in the turn-of-the-century farming colony of Edenbridge, Saskatchewan comprised Yiddish books that were transported in a rucksack from farm to farm and read aloud (Jones 2006).

[25] In Montreal, an amalgamation of collections of Yiddish works of leftwing thought and belles-lettres formed the backbone of Montreal's Jewish Public Library. Officially founded in 1914, the Library was established as a non-partisan community lending library and cultural centre in the Jewish immigrant quarter. In its early years, it offered an array of courses and events via its Folksuniversitet (People's University), a venture that was subsequently revived in 1941. In addition to providing a place for the immigrant community to acquire reading material and to gather, the Library served as a heart of local Yiddish literary activity, offering 
presentations by local and visiting writers, book launches, celebrations of milestones in the Yiddish world, and public lectures.

[26] Schools for children emerged as a locus of Yiddish cultural activity. With Canadian children funnelled into English institutions for their full-day schooling, Jewish education was initially provided by supplementary schools connected with local synagogues or by a transplanted version of the kheyder system that centred on traditional Jewish textual learning; by the 1890s, parents had the option of more modern Talmud Torah schools. The absence of nonsectarian schools in Canada promoted new ventures in Jewish education. In particular in Montreal, where the Jewish community formed a self-contained "third solitude," the exclusionary character of the denominational school system helped to encourage the creation of a system of modern secular Jewish schools of a nationalist orientation (Tulchinksy 1984). These Yiddish schools_-known as shuln (sing. shul)—played a central role in the long-term maintenance of Yiddish culture as well as wider group identification and social cohesion. Thus, in an article about the city's shuln published in the New York's Tog-morgn zhurnal in the 1950s, journalist Ben Zion Goldberg (Waife) remarked, "if there was ever the possibility of cultural Jewish/Yiddish autonomy in Anglo-North America, it was in Montreal" (1955).

[27] On the eve of World War I, Canada was at the forefront of the North American development of a modern secular Yiddish school system. The impetus was a wider twentieth century advocacy for Yiddish that marked the beginnings of its formal pedagogy; as Shandler points out, "for Yiddishists, the classroom became the venue par excellence for enacting a modernist transformation of traditional Ashkenazic culture" $(2006,71)$. Despite their vast Yiddish populations, both Tsarist Russia and the United States were delayed in their development of a comprehensive system of secular Yiddish education until the interwar period; the former was 
hindered by state suppression, and the latter by the cosmopolitan ideology of the post- 1880 wave of immigration that initially promoted English-language education for the Jewish masses (Michels 2005). In contrast, Canada's mass immigration, characterized by a strong nationalist orientation, promoted Yiddish as well as Hebrew as expressions of Jewish identity in its schools from the onset (Roskies 1990).

[28] The first Canadian shuln were founded in the wake of a Poale Zion conference held in Montreal in 1910, where Yiddishist ideologue Chaim Zhitlovsky proposed a system of "natsyonale radikale shuln (National Radical Schools)" to transmit the movement's core Zionist and Socialist values. National Radical Schools with Yiddish as the core of the curriculum were founded in Montreal, Winnipeg and Toronto by 1914; these were renamed Peretz Shuln after the death of Yiddish writer I.L. Peretz in 1916 (Corcos 1997, Speisman 1979, Victor 2002). In the teens, Yidishe Folkshuln (Jewish People's Schools) were formed in Montreal and Toronto, distinguished by their increased emphasis on Hebrew in the curriculum. In the 'twenties and 'thirties, shuln in smaller Jewish centres such as Calgary, Edmonton and Vancouver were founded along similar lines. These shuln offered Yiddish supplementary education in language, Jewish literature, folklore and history, and promoted diverse leftwing ideologies, with a variable role attributed to Hebrew (Gutkin 1980). By the end of 1920s, shuln in Winnipeg and Montreal were offering day school education, with Montreal's Morris Winchevsky Shul following suit from the mid-1940s through the early 1950s. The Canadian development of Yiddish full-day education parallels developments in Latin America (see Levy 1987); in contrast, the secular Yiddish schools in the United States, despite their rapid expansion, remained a supplementary system to complement the public day schools (see Parker 1981). 
[29] The shuln promoted student commitment to Yiddish language and culture, as the example of the Montreal Yiddish day schools reflects. All of these institutions-the Peretz Schools, Jewish People's Schools and Morris Winchevsky School—featured classes in Yiddish literature and composition, and encouraged the students to actively engage with Yiddish literature by discussing, declaiming and authoring belles-letters. At every opportunity, the shuln invited literary guests to the city into the classroom or school assemblies. They sponsored shul clubs and journals to encourage student publication in Yiddish. Moreover, many of the schools' teachers were themselves published poets and authors, including Shimshen Dunsky, J.I. Segal, Sholem Shtern and Yaakov Zipper. Always understanding themselves as an integral part of the wider community, the shuln offered programming for adults, and organized school events where performance of literature formed the focal point. In 1929, poet J.I. Segal expressed the shuln's holistic approach to Yiddish education in the face of opposition from elements of the community: "I see us all as one camp: poets, artists, writers, teachers, journalists, cultural activists and cultural builders. I see us all as one edifice, one venture" $(1929,46)$. Despite perceptible Yiddish attrition among the student body as early as the 1920s, shuln activists worked to promote Yiddish as a creative living language. The memoirs of Jewish People's School principal Shloime Wiseman provide insight into these ongoing efforts:

I recall going around in the hallways or in the yard at recess and telling the students, 'redt Yiddish (speak Yiddish).' This went on for several years until we got sick of it, and concluded that it was pointless. This did not, however, cause deterioration in the instruction of Yiddish in class; rather, the requirement that children speak Yiddish was limited to the classroom during interactions with the teacher, answering questions, or recounting the contents of a paragraph. Much emphasis was placed on writing. Composition class came to occupy an important position $(1982,391)^{7}$

[30] The Montreal shuln came to embody a community's hopes for future-oriented secular Yiddish culture, in particular in the cultivation of young writers. The wider Yiddish literary 
world thus rejoiced when Peretz School graduate Rivke Royzenblat published a book of verse in 1929; its forward by leading New York literary critic Sh. Niger refers to Lider (Poems) as "the first collection by a Yiddish poetess who grew up and was raised in Canada. It is the first, tender fruit of the new Yiddish education in the world. ... This is the first quiet gift to Yiddish literature from the Yiddish school in America, a gift that will be accepted with joy" (Royzenblat 1929, i). A quarter century later, the publication of Gut morgn dir, velt (Good Morning To You, World) by thirteen year-old Morris Winchevsky School student Aaron Krishtalka caused a sensation in literary circles (1953); Sh. Niger's review remarked that Krishtalka's poems "awaken in us the hope for a new generation of young Canadian Yiddish writers" (1954). These Canadian-raised writers were seen as harbingers of a viable Yiddish cultural life. Although neither established careers as Yiddish writers, Royzenblat and Krishtalka remained engaged with Yiddish in the longterm: she as Yiddish folklorist and singer Ruth Rubin, ${ }^{8}$ and he by continuing to write and publish Yiddish poetry as a young adult.

\section{Yiddish Theatre}

[31] While Canada was at the forefront of the modern Yiddish school movement, its smaller consumer base and proximity to New York hindered the development of local theatre in much the same way as the press: it was easier to import than create (Ravitch 1963, 77). In both Europe and its immigrant centres, the Yiddish theatre attained wild popularity among the Jewish masses, with a proliferation of professional troupes performing repertoire that ranged from popular melodramas to art theatre (see Sandrow 1996). New York, which emerged as the mecca of North American theatre, supplied both material and talent to Yiddish communities worldwide (Warnke 2004). Until the 1950s, most of the Yiddish theatre produced across Canada consisted 
of popular musical dramas with casts largely imported from New York; it was simply easier and cheaper to bring in troupes on a rotational basis than to cultivate local talent (Larue 1996). Toronto's Standard Theatre, built in the heart of the Jewish immigrant district in 1921 as a Yiddish theatre, offered serious "art" productions as well as melodramas, but did not house a permanent troupe. Montreal's home of Yiddish theatre for over half a century was the Monument National, which had been erected in 1894 as a bastion of French Canadian culture and subsequently rented out to local community groups. Again, repertoire troupes and stars of the Yiddish stage were imported from abroad. High-calibre local amateur theatre emerged on the eve of World War II, when renowned Soviet-trained former Habima actress, Chayele Grober, found herself stranded in Montreal and decided to found a Yiddish drama studio. From 1939 through 1942, the YTEG (Yidishe Teater Grupe/Yiddish Theatre Group) trained local actors in the Stanislawski Method and devoted itself to improvisations and short etudes inspired by a poem or short story that group members worked into scenes involving movement, singing, music, and dance. However, it was not until the late 1950s that Canada would house a permanent Yiddish theatre.

\section{Canadian Yiddish Culture After 1950}

[32] Despite its strong institutional base, Yiddish succumbed to English in its role as the dominant lingua franca of the Canadian Jewish community by 1950. The demographic decline combined with the destruction of the Yiddish heartland in the Holocaust transformed the functions of the language in Jewish life. While activists persevered in their promotion of the language and culture, Yiddish moved from a dominant force in the community to the margins. Moreover, the Holocaust prompted a profound reorientation towards Yiddish. Canadian Yiddish 
artists and activists such as poet J.I. Segal increasingly "began to sanctify the language of those who had died" (Rosenfarb 2007, 15). As Anita Norich has suggested, Yiddish became anthopomorphized to "metonymically stand" for the speakers lost in the Holocaust in a "rhetoric of loss" $(2007,5)$. On the whole, the Canadian Jewish community transitioned from active to passive engagement with Yiddish, at least in the realm of secular culture. While the community's engagement with Yiddish has shifted markedly, major components of the infrastructure to support Yiddish have remained, with new forms coming into play.

\section{Yiddish Literature and Publishing}

[33] Perhaps nothing is more emblematic of the deep shift in Yiddish culture than the transformation of Yiddish publishing. As Yiddish declined as Jewish lingua franca, the circulation of the Yiddish press fell steadily until its newspapers folded one by one. Montreal's Keneder Adler appeared as a daily until 1963 and then as a weekly until 1988; Winnipeg's Dos yidishe vort and Toronto's Der yidisher zhurnal appeared as weeklies into the 1980s. Today, there are no regularly published Canadian Yiddish periodicals, although the Anglo-Jewish weekly Canadian Jewish News, which appears in both Montreal and Toronto editions, features a Yiddish column. The Hasidic community occasionally publishes community periodicals with Yiddish content (Lapidus 2007). Canadian readers subscribe to Yiddish newspapers and journals from abroad.

[34] This attrition paradoxically coincided with an upsurge in Canadian Yiddish book publication. In the face of a dwindling readership, writers increasingly published works with community support. Of particular importance was the bukh-komitet, a provisional book committee $^{9}$ assembled to finance, oversee the production and distribution, and ultimately 
celebrate the publication of a volume. Other writers took on the full responsibility of publishing and distributing their works, and encountered the growing challenge of finding an audience. As Yiddish increasingly became a heritage language, the readership for these books has gotten smaller and smaller. Most of the small Yiddish libraries have vanished, with Montreal's Jewish Public Library reflecting an increasingly linguistically diverse Jewish community: today it offers reading and audiovisual material as well as cultural programming in English, French, Hebrew, Yiddish and Russian. At the same time, new Jewish libraries have been founded: the Toronto Latner Jewish Library (formerly the Jewish Public Library of Toronto), founded in 1941, includes a Yiddish collection. Vancouver's Peretz Centre for Secular Jewish Culture (formerly the Vancouver Peretz Institute) introduced a Yiddish library in 1953 that became a permanent fixture of the Institute in 1977; it remains the last Yiddish library in Western Canada (Jones 2006). As Faith Jones has observed, although the actual books enjoy very limited circulation, "these libraries form one component of Yiddish language activism, which literary critic Irving Massey has identified as a highly 'group-aware' movement in which the needs of the community and the greater good of its members become inextricably bound up with language" $(2006,65)$. At the same time, personal libraries are discarded. The remarks of Ron Feingold, former librarian at the Jewish Public Library, capture the trend, "I see Yiddish libraries that were built up sixty or seventy years ago being thrown out now because nobody can read them. It's all being abandoned—don't tell me it's carrying on!" (Abley 2004, 209). The bulk of Canada's surviving Yiddish books are found in libraries and archival collections, or at the National Yiddish Book Centre (NYBC) in Amherst, Massachusetts.

[35] The story of the NYBC — the largest repository of Yiddish books in the world—is, in part, a Canadian one. Its roots lie in late 1970s Montreal, when its founder, Aaron Lansky, then a 
graduate student at McGill University, found himself unable to find the Yiddish books he needed for a course. His call for books in the Montreal Yiddish community opened a floodgate that would propel him and his team of zamlers (book collectors) across the world to rescue over a million Yiddish books. Founded in 1980 as a non-profit organization whose mandate is to "rescue Yiddish and other modern Jewish books and celebrate the culture they contain" the NYBC offers originals as well as reprints of thousands of digitized titles, which are redistributed worldwide, largely to universities and students (National Yiddish Books Center). ${ }^{10}$ From the onset, Canadians have been integral to the NYBC's collection efforts with zamlers across Canada yielding thousands of books_-in particular from Montreal, Toronto and Winnipeg. Lansky's memoirs spotlight the continued vitality of the Canadian Yiddish literary milieu: in the late 1970s, Sara Rosenfeld, the head of the Canadian Jewish Congress's National Committee on Yiddish, "mobilized a country" to collect Yiddish books across Canada; trips to Montreal routinely "yielded a disproportionately large proportion of treasures," in particular from the sizable group of intellectuals that had arrived after the Holocaust, which included spouses and children of Yiddish writers such as poet Rokhl Korn (2004, 228-9). On a deeper level, the NYBC's activities reflects the profound reorganization of the Canadian — and international— Yiddish cultural scene as the literary holdings of entire communities are steadily being dismantled and exported to what has become a major Yiddish heritage site. While the books remain "powerful cultural catalysts" (Shandler 2006, 176), the terms of engagement have shifted from goods that are actively produced and consumed by a mass audience to objects that carry symbolic value but have become the purview of a shrinking readership.

\section{Yiddish Education}


[36] Similar shifts have occurred in the realm of education, with each generation further removed from the Yiddish vernacular. Shul pedagogues faced an increasingly uphill battle to maintain a Yiddish-centred environment, and sponsored mechanisms such as clubs and student publications to encourage Yiddish use among an increasingly English-speaking student body. With the decline of leftist ideologies among the community, the increased status of Hebrew after the creation of the State of Israel, and a shrinking clientele for Yiddish education, many of the shuln closed their doors or merged with other Jewish schools, while others slashed the instruction of Yiddish within the curriculum. For example, Winnipeg's Peretz Folk Shul lost its Yiddish component in its amalgamation with the local Talmud Torah in 1983.

[37] Today, Canada houses some of the world's few non-Orthodox Jewish day schools where Yiddish study is compulsory. In continuity with their roots, both the elementary and high school levels of Montreal's Jewish People's and Peretz School (JPPS) system, which merged in 1971, offer Yiddish. With few, if any, of the students experiencing Yiddish as a day-to-day language, the instruction is focused more on establishing a connection with Ashkenazi culture than linguistic fluency:

JPPS recognizes the primacy of Hebrew as the language of the entire Jewish people. Nevertheless, in its educational philosophy and orientation, this school has, from its very beginning, integrated the study of Yiddish language and literature into the curriculum of the school. This program of studies is viewed as the vehicle to make the students more knowledgeable and appreciative of this unique and particular part of their Jewish heritage and culture (JPPS Elementary School).

Yiddish also features on the curriculum of Toronto's Bialik Hebrew Day School, founded by labour Zionists in 1961 as “a natural extension" of the city's already existing Jewish People's School. In contrast with Hebrew, which is taught as a "modern spoken language" in an 
immersion program beginning in first grade, Yiddish instruction emphasises the symbolic value of the language:

Our Yiddish language program, unique among Jewish day schools, creates a wonderful bridge between our past and present, between grandparents and grandchildren. The Yiddish culture of the pre-Holocaust era is taught through song, drama and humour, and through the study of classic Yiddish authors and poets (Bialik Hebrew Day School).

This approach is akin to Shandler's findings in his study of American Yiddish pedagogy, which posits that the language has increasingly taken on symbolic value as "an object of heritage" (2000).

[38] In seemingly sharp contrast to the secular Jewish schools, Hasidic education continues to embody the traditional diglossic system of study, with loshn-koydesh as the high-function written language and Yiddish as the low-function vernacular (Baumel 2005, Shaffir 1974). Schools in the community have been instrumental in promoting Yiddish linguistic vitality, albeit unevenly. Gender segregation has created variable patterns of Yiddish education and maintenance: Yiddish is the dominant language for boys both inside and outside of school, whereas girls, who receive more English-language instruction, are less likely to speak Yiddish amongst themselves.

Research on Britain's Hasidic communities point to a "thriving case of ethnic mother-tongue revitalization" through a renewed emphasis on Yiddish use in the schools (Glinert 1999, 31). In many schools in England, for example, Jewish studies are taught in Yiddish, albeit with minimal, if any, formal instruction in the language. Even in the Lubavitch movement, where Yiddish use is relatively weaker, some schools have introduced Yiddish instruction (see Glibert 1999, 45). Members of the Montreal area community tend to identify purely pragmatic uses for Yiddish education, as reflected in the words of Alex Werzberger, president of the Coalition of Outremont Hasidic Organizations (COHO): "We understand and read Hebrew, but we do not speak it, 
because it is a holy language. That's why some Bibles have half the page translated into Yiddish. We sit down with the child and explain that God spoke to Moses in Hebrew, but then we'll translate it right away into Yiddish so he will understand" (Heinrich 2008). However, Shandler identifies the curricularization of Yiddish among Hasidim "as an exercise in heritage that is responsive to their own concerns" $(2000,114)$. In the final analysis, Yiddish education among Hasidim is as much a deliberate choice as for its secular counterpart.

\section{Secular Yiddish Culture}

[39] A secular Yiddish culture has evolved into an increasingly accessible milieu. One fixture on the secular Yiddish cultural scene is the Jewish secular humanist movement. With an ideology based on identity via Jewish values of social justice combined with Jewish diaspora culture, Yiddish has become a means for secular Jews to forge connections with aspects of their heritage that are not inextricably linked with religious observance or statehood. These associations date back a century to Chaim Zhitlovsky and I.L Peretz, both of whom promoted the creation of a complete Yiddish culture (Fishman 2005). A primary vehicle for this movement is the Fareynikter Yidisher Folks Ordn/United Jewish People's Order of Canada (UJPO). Founded in April 1945 as a merger of far-left Jewish groups in Montreal, Toronto and Winnipeg, the UJPO has evolved into a leftist secular cultural and educational organization with a mission statement that spotlights Yiddish: the UJPO "develops and perpetuates a progressive secular approach on social and cultural matters, our Jewish heritage, the Yiddish language and holiday and festival celebrations; we sponsor secular Jewish education, musical and cultural groups, concerts, lectures, public forums, and take part in social action and related community activities" (UJPO). 
[40] The UJPO has been active in sponsoring supplementary schools for children, cultural programs and choirs where Yiddish is taught and sung. At its height from the 1930s through the 1960s, the Montreal branch sponsored a community centre as well as the Morris Winchevsky Schools. The Toronto branch continues to support a Morris Winchevsky School, a Jewish Folk Choir, and bungalow colony called Camp Naivelt; the Winnipeg chapter is affiliated with a conversation circle called the Mame-Loshn Group and the Sholem Aleichem Sunday School. With collectives across Canada, the Vancouver branch publishes Outlook, a Jewish magazine that features Yiddish poetry with translation and other Yiddish content. Moreover, many Vancouver-based UJPO members are affiliated with the Peretz Centre for Secular Jewish Culture, which was founded in 1945 "in response to the threat to Jewish culture and Yiddish language posed by the Holocaust and WWII" (Peretz Centre for Secular Jewish Culture). With “secular humanist Yidishkayt" at its core, the Peretz Centre's activities include programming for seniors, a Sunday school for children, Yiddish classes for adults, and the Vancouver Jewish Folk Choir. This programming embodies one of the characteristics of today's Canadian secular Yiddish cultural milieu: it attracts both Jewish and non-Jewish participants. More generally, it also reflects the more fluid experiences of Jewishness that characterize contemporary Jewish identity and institutional life in North America (Pomson and Schnoor 2007).

\section{Yiddish Scholarship}

[41] Scholarship forms another realm in which secular Yiddish culture has increasingly entered the Canadian mainstream. In contrast to ideologically motivated academic programs established in Poland and the Soviet Union during the interwar years that institutionalized Yiddish-language research in areas such as philology and folklore, post-War Yiddish scholarship-which is 
conducted primarily in English or Hebrew—has become increasingly professionalized and interdisciplinary (Prager 1981, Krutikov 2002). Today's field of Yiddish includes many scholars and academics of Canadian origin, many of them graduates of the modern secular Yiddish schools. However, their level of ideological commitment to Yiddish varies. Winnipeg-raised Sheva Zucker, translator, author of Yiddish educational materials and Executive Director of the League for Yiddish in New York, stands out as an individual with professional links to Yiddish both within and outside of the academy. Within the university setting, Yiddish courses are being offered under the rubric of minority or heritage languages at institutions of higher learning worldwide, with rising enrolment (MLA, Virtual Shtetl), including Canadian universities such as McGill University, University of Ottawa, University of Toronto, and York University. Students come from a variety of backgrounds, both Jewish and non-Jewish, some seeking family roots, others seeking to engage with a new ethnic tradition.

\section{Yiddish Theatre}

[42] The Dora Wasserman Yiddish Theatre is emblematic of the wider transformation of Yiddish culture from popular entertainment to a vehicle for promoting both Yiddish heritage and crosscultural exchange. After her arrival in Montreal from a Displaced Persons' camps in 1950, Soviet-Yiddish actress Dora Wasserman began to instruct local children in Yiddish drama through the local Yiddish schools and the Jewish Public Library. By 1956, she had founded the Yiddish Drama Group, a troupe comprised largely of graduates from the Jewish People's Schools. Drawing on her own training in the GOSET (Moscow Yiddish Art Theatre) under legendary director and actor Solomon Michoels, and with logistical support from Quebecois theatre pioneer Gratien Gélinas, she began to produce high calibre musicals and dramas for adult 
audiences. With Yiddish theatre becoming increasingly rare after the 1960s, Wasserman's company was recognized not only as a community institution, but as a "symbolic stronghold," with Wasserman called "the great defender of Yiddish culture." This shift is reflected in a 1962 interview with the Montreal Gazette in which Wasserman stated her goals for the preservation of the language and its culture through the theatre: "We are convinced that Yiddish is still very much a living, breathing language and a significant component of Jewish life" (cited in Larrue 1996, 117). By 1967, Wasserman's Yiddish theatre had become established as the resident theatre company of Montreal's Saidye Bronfman Centre for the Arts.

[43] As North America's only permanent resident Yiddish theatre, the Dora Wasserman Theatre has produced dozens of plays with a varied repertoire. These include Yiddish classics as well as original adaptations of Yiddish works by Nobel Laureate Isaac Bashevis Singer, and specially commissioned Yiddish translations of plays such as Michel Tremblay's Les Belles Soeurs. The audience for these annual productions spans the Jewish and wider communities, with simultaneous translation into English and French available. The group has also toured Canada, the United States, Europe, and Israel. With Dora's daughter Bryna Wasserman at the helm since 1998, the theatre has coordinated local and touring Yiddish productions as well as a smaller troupe called "Wandering Stars" that performs at smaller venues and festivals. The group's three-pronged mission reflects the expanded role of Yiddish theatre in contemporary Canada:

1. To dramatize the Jewish experience: Yiddish Theatre [sic] reflects the whole panorama of Jewish life, the Yiddish language and literature, the traditions and turbulent history, the philosophy and folk wisdom and the humour, the poetry and the music.

2. To sustain Yiddish language and culture in Canada and around the world: The Dora Wasserman Yiddish Theatre is a major centre for the development and promotion of the Yiddish legacy as a living, vibrant culture wherever Yiddish was once spoken and is spoken.

3. To foster intercultural understanding through the arts: Across Quebec and Canada and abroad, The Dora Wasserman Yiddish Theatre is seen as a cultural 
ambassador for the Jewish community and as a proud example of this country's openness to diversity (Dora Wasserman Yiddish Theatre).

Moreover, the theatre promotes Yiddish vitality by continually mounting new work. However, if Mark Abley's description of a recent production is any indication, despite Wasserman's efforts, the Yiddish theatre is the purview of an increasingly aging population, both in its participants and audiences (2004).

[44] One way in which the Dora Wasserman Yiddish theatre has promoted the involvement of the younger generation is through its youth wing, YAYA (Young Actors for Young Audiences). Its mission statement is directed at all young people, regardless of their background: "Through the medium of theatre, YAYA offers youth the chance to experience Jewish heritage and Yiddish language and culture." In 2003, this venture expanded to include anti-discrimination activism through a production called No More Raisins, No More Almonds: Children's Ghetto Songs, which was written by Holocaust survivor and Jewish educator, Batia Bettman to sensitize teenagers across Canada to the lessons of the Holocaust. Comprised of English dialogue and Yiddish songs (with English and French subtitles), performances across North America have included "talkbacks" between the YAYA actor, and their school-aged audiences. The play has served as a catalyst for intercultural dialogue about the effects of prejudice among largely nonJewish groups (Lampert 2003). The show's stated aims include "sustaining Yiddish culture and language, dramatising the Jewish experience and fostering intercultural understanding through theatre" as well as "an education and leadership-training component" as the actors learn about the Holocaust." The larger goal of the production is to transform the actors into "youngsters committed to improving the world." Here Yiddish is a vehicle for employing the lessons of the Holocaust to combat racial and religious bigotry. 


\section{Yiddish Music}

[45] Yiddish as a site of heritage has become a key characteristic of the contemporary Canadian Yiddish music scene, in particular in the genre of klezmer music. After a steep decline among North American immigrant Jews in the first half of the twentieth century, the late 1970s marked the beginnings of a reclaiming/revival/re-activation — the term is a subject of debate-of "klezmer music" $" 11$ by new generations of musicians. With klezmer originally referring to a member of a caste of professional travelling instrumentalists who played at prescribed community functions such as weddings and holiday celebrations, klezmer has morphed into popular entertainment (Feldman 2002). The proliferation of klezmer worldwide includes dozens of bands across Canada (Canadian Klezmer, Klezmer Shack). Ethnomusicologst Mark Slobin posits that klemzer has evolved "a set of recognized symbols" that allow outsiders to cross ethnic boundaries $(1984,38)$; at the same time, klezmer is used to fill "the cultural chasm caused by the Holocaust" (2000, 22). With ever-evolving frameworks for transmission and performance, klezmer music has become a forum for both intergenerational and intercultural exchange. [46] Toronto’s biennial Ashkenaz Festival creates an inclusive and accessible heritage experience that draws on klezmer music. Founded in 1995, the festival bills itself as "one of the world's largest public celebrations of Yiddish and Jewish culture," with dozens of artists performing around Toronto to thousands of spectators. As Shandler points out, broader than its original "festival of new Yiddish culture," the new billing is more fitting, given that actual Yiddish use at Ashkenaz is sporadic $(2003,143)$. The mandate is geared towards inclusiveness and building partnerships and forging new expressions of Jewish culture among emerging artists:

The Ashkenaz Foundation is a community-based non-profit organization dedicated to fostering an increased awareness of Yiddish and Jewish culture through the arts. Ashkenaz places an equal emphasis on the need for preservation and innovation within this cultural milieu. Ashkenaz incorporates in its mandate 
and programming many other manifestations of Jewish music and art beyond Klezmer/Yiddish, and actively pursues fusion and cross-cultural exchange with artists from outside Jewish cultural traditions through commissioned work and special projects (Ashkenaz Festival).

Ashkenaz embodies Kirshenblatt-Gimblett's concept of klezmer as "heritage music": "I use the term heritage music to distinguish between music that is part and parcel of a way of life and music that has been singled out for preservation, protection, enshrinement, and revival" (2002, 134). In this framework, Yiddish becomes a place for anyone-with or without roots in Ashkenaz—-to visit and experience "Yiddishland" as cultural tourists in what amounts to a “'festivalization' of sites of ethnic and national memory" (Shandler 2003). Festivals such as Ashkenaz have become a way for anyone to visit a mythic Jewish past and create new expressions of Yiddish culture.

[47] KlezKanada evinces a similar festivalization of Yiddish. Founded in 1996 and annually held at a camp outside of Montreal, KlezKanada bills itself as "the internationally renowned and only rural based summer festival of Yiddish/Jewish culture and the arts in North America" (KlezKanada). The event hosts hundreds of participants of all ages from across Canada, the United States, Europe and Israel, and offers concerts, workshops in klezmer instrumental and vocal technique, classes in Yiddish language, art and dance, and lectures about Yiddish culture. The stated goal of these gatherings is "to foster Yiddish and Jewish cultural and artistic creativity as both an ethnic heritage and a constantly evolving contemporary culture and identity." While Yiddish features prominently in the music and lecture themes, the language of programming is almost exclusively English. This is because organizers of events that celebrate Yiddish culture such as KlezKanada “cannot assume that participants' devotion to the language's secondary, symbolic level of meaning is matched by their own competence in Yiddish at its primary, vernacular level" (Shandler 2006, 139). As KlezKanada founder Hy Goldman says, "We’re 
using Yiddish not simply to try and keep it alive, but to get through (sic.) a sense of Jewish identification" (Abley 2004, 219).

\section{The Legacy of Secular Yiddish Culture in Montreal}

[48] The last decade has brought a sharp erosion of Canadian secular Yiddish culture rooted in

pre-Holocaust Europe, in particular in its centre of Montreal. Yiddish scholar Dovid Katz characterizes the impact of recent losses:

For anyone to whom modern Yiddish, and its literature and culture are dear, the most bitterly painful time is the present. The secondary Holocaust blow is hitting hard and is coming to its devastating climax. The last secular Yiddish masterswriters, teachers, cultural organizers, scholars, journalists, performers, artists and so on, who came to intellectual or cultural maturity in pre-Holocaust Eastern Europe, are disappearing daily. In mid-2003, Montreal, for example, was still on the conceptual map of high-end secular Yiddish culture because of the presence of great prose writer Yehuda Elberg (born in Poland in 1912); the untiring, inspirational organizer of Yiddish cultural institutions and events, Sara Rosenfeld (born in Poland in 1920); and the fabled founder of Canada's Yiddish theatre, Dora Wasserman (born in Ukraine in 1919). By mid-2004, they were all gone. It is rather unfair to complain to God (or to doctors) when people in their eighties and nineties who have lived through a lot come to the end of life in peace surrounded by loved ones. By later 2004, Montreal, with no disrespect to its many enduring Yiddish resources (far outstripping many cities with much larger Jewish populations), had fallen off the map as a center boasting major living masters (Katz 2004, 349).

[49] Montreal's post-Holocaust prominence in the Yiddish world can be attributed to two factors: the pre-existence of a strong institutional base for Yiddish, and the high proportion of Holocaust survivors who made the city their home. This group revitalized local Yiddish cultural life by both forming and reviving local organizations (Giberovitch 1996) and helped to transform Montreal from a minor to a major Yiddish centre. In the decades following World War II, the city housed some of world's most prominent Yiddish cultural figures, including poet Rokhl Korn; poet and essayist Melekh Ravitch (Zekharye Khone Bergner); and novelist Chava 
Rosenfarb. In an interview, Rosenfarb describes the Yiddish literary scene she encountered upon her arrival in 1950: "Not in vain was it called 'the Jerusalem of North America.' ... Take the Jewish Public Library! It was the centre, the vital nerve of Yiddish life in North America, not just in Canada. And the great Yiddish writers from New York used to come to Montreal. I met them all, here in Montreal" (Naves 1994, 58). Even with Yiddish ceasing to be the daily language of much of the Canadian Jewish community, institutions have persisted. Thus Yiddish translator Goldie Morgentaler—Rosenfarb's daughter—attributes her upbringing in Montreal with her retention of the language: "Because Montreal managed to preserve its Yiddish heritage for so long, to institutionalize it, and to offer it some organizational and cultural backing, the language held onto its vibrancy in a way that it did not in other places" $(2007,104)$. Thus, Montreal produced one of the estimated dozen secular writers born after the Holocaust to publish books: Jewish People's and Peretz Schools graduate Leybl Botwinik, author of Geheyme shlikhes (Secret Mission) in 1980 at age twenty-one (Katz 2004, 372).

[50] Rosenfarb remains one of the last Mohicans of Yiddish literature. Even with the resilience of Montreal's cultural milieu, she has expressed the profound alienation of the Yiddish writer:

What affects me most is the continual sense of isolation that I feel as a survivor, an isolation enhanced by my being a Yiddish writer. I feel myself to be an anachronism wandering across a page of history where I don't really belong. If writing is a lonely profession, the Yiddish writer's loneliness has an additional dimension. Her readership has perished. Her language has gone up with the smoke of the crematoria. She creates in a vacuum, almost without a readership, out of fidelity to a vanished language, as if to prove that Nazism did not succeed in extinguishing that language's last breath, that it is still alive" (cited in Abley 2004, 112).

A survivor of the Lodz Ghetto and the Auschwitz and Bergen-Belsen death camps, Rosenfarb has chronicled the survivor experience in novels and short stories. In order to reach a readership, 
Rosenfarb has engaged in an ongoing project to translate her Yiddish novels and prose into English together with Goldie Morgentaler.

\section{Yiddish Translation}

[51] Like Rosenfarb, many Yiddish writers have addressed the loss of a readership through translation. The pioneer of Canadian Yiddish literary translation is Montreal poet Sholem Shtern, an immigrant to Montreal of the 1920s and author of novels in verse depicting Canadian Jewish immigrant life. Beginning in the 1960s, Shtern initiated translation into both English and French, with all of his novels appearing in both languages by the mid-1980s (Margolis 2007). Polishborn writer Yehuda Elbert, a Holocaust survivor who arrived in Montreal via Paris and New York in 1956, likewise had a hand in the translation of his work. He was involved in the translation into English of two of his best-known novels, and served as a resource for a French translation by québecois scholar, Pierre Anctil (Margolis 2008). Toronto lyricist Simcha Simchovitch, "the last Yiddish poet in Canada," is engaged both in Yiddish writing and translation of his own original work as well as the writing of others; his most recent work is a bilingual Yiddish-English compilation of his poetry (Schwartzberg 2008).

[52] Beginning in the 1970s, a group of young Montreal anglo-Jewish writers and poetry embarked on a venture to translate Canadian Yiddish literature into English (Butovsky and Garfinkle 2007, 36). In the last three decades, a dozen anthologies of Canadian Jewish writing have featured Yiddish poetry and prose. Since the 1990s, Pierre Anctil has translated Yiddish volumes of belles-lettres, memoir and history into French, while Vivian Felsen has rendered works of non-fiction into English. These translations have not only made Yiddish texts accessible to non-Yiddish audiences but opened up a side of the Canadian Jewish experience previously unknown to most readers (Margolis 2008). Moreover, despite a comparatively 
limited market, Canada marks the site of innovative projects in Yiddish translation. Groups of Canadian translators have worked collectively to publish two recent anthologies of Yiddish women's writing (Forman et. al. 1994, Tregebov 2007). Finally, the translation of a Yiddish memoir by Winnipeger Martin Green has been called "the most unusual and semiotically provocative permutation of Yiddish translation in the postvernacular mode" (Shandler 2006, 123). Green's translation of Falk Zolf's 1945 memoir, Oyf fremder erd (On Foreign Soil) gradually introduces glossed and transliterated Yiddish terms into the English text until the text "turns to Yiddish," all in English characters (Zolf 2000). In the process, the text "provides the modern reader with an unprecedented opportunity to re-connect in a meaningful way with the disappearing heritage that is the Yiddish language" (On Foreign Soil).

[53] Translation broadly defined represents an increasingly important locus for the Canadian engagement with Yiddish, as reflected in a 2004 conference titled "Traduire le Montreal Yiddish/New Readings of Yiddish Montreal/taytshn un obertaytshn yidish in montreol.” The event, which brought together scholars, writers and translators, both from within and outside of the Yiddish community, embodied many of the modes of engagement with Yiddish that co-exist in Canada today. Chava Rosenfarb opened her keynote: "I consider myself a makhateneste (son/daughter-in-law's mother) at every gathering where Yiddish is being celebrated. Despite the fact that so many years ago I was torn out of my Yiddish-speaking world, my heart and mind are still rooted in it. Yiddish is still the language of my daily life. It is the medium through which I come in contact with my surroundings, and through which I try to harness my life's experiences and recreate them into literature" $(2004,11)$. Against the backdrop of her own lifelong engagement with Yiddish, Goldie Morgentaler called for the need for translation to preserve, "no matter how inadequately, the once vibrant creativity of the Yiddish-speaking community of 
Montreal" (2007). Vivian Felsen described discovering the legacy of her grandfather, Yiddish journalist Israel Medres, via the French-language translations of Pierre Anctil (2007). Québécois essayist, poet and novelist Pierre Nepveu spoke of his "knowledge" of a language that he neither understands nor speaks, but accesses through the lens of translation into French (2007). Cultural scholar Sherry Simon posited that Yiddish has become part of a wider conversation about ethnicity and cultural hybridity (2007). These modes are in flux and constantly expanding.

\section{Hasidim and Yiddish}

[54] In the final analysis, the members of the Canadian Jewish community with the most direct and ongoing contact with Yiddish remain its Hasidim. The Yiddish-speaking Haredi communities remain the fastest-growing segment of the Canadian Jewish community due to their high birthrate. For example, the Tash community has grown from eighteen to some 250 families in forty years; according to a Tasher official, couples average one child for every 1.5 years of marriage, with about two births per week in the community (Kiryas Tash). These children are largely being raised and educated in Yiddish. If we can assume parallels with Glinert's findings on Britain's Hasidic communities, "the future of Yiddish appears to be bright" $(1999,49)$. [55] While Yiddish is promoted as having value among Hasidim, that worth is primarily utilitarian rather than aesthetic. It encourages distinctiveness and group solidarity, and facilitates communication among Haredim worldwide. For Lubavitch Hasidim, it allows speakers to access the Yiddish teachings of their last rebbe, Menachem Mendel Schneerson (a.k.a. the Lubavitcher Rebbe). However, as Betzy Goldberg, a member of the Montreal Hasidic community, points out, although Yiddish is a mother tongue and widely used, “we don't speak Yiddish to preserve the language, but to have a connection with our forefathers ... The language keeps us between ourselves and minimizes outside influence" (Heinrich 2008). While members of Montreal's 
Hasidic community do publish community material with Yiddish content (see Lapidus 2007, Hatzolah Kyrias Tosh), Yiddish itself—spelling, style, new vocabulary—is not cultivated. This worldview is expressed by Werzberger: "Yiddish is not a language. Yiddish really is a jargon, a joual. ${ }^{12}$ It's a bastardized version of German. Hebrew and Yiddish are not even third cousins" (Abley 2004, 224). This sentiment, rather ironically, echoes the rhetoric of the nineteenth century Jewish modernizers who sought to wean Europe's Jews away from Yiddish and the "Jewish ghetto." In a culture that prioritizes receptive textual knowledge and shuns secular culture, Hasidim are neither consumers nor producers of modern Yiddish literature, at least not officially (Glinert 1999). While they do not value the cultivation of written Yiddish per se, Hasidim are reading Ultra Orthodox Yiddish newspapers such as New York's Algemeyner zhurnal, which promotes Yiddish as a means of combating assimilation (Baumel 2003, 94-95). Newcomers to Lubavitch are expressing interest in learning Yiddish in order to better identify with the group and its teachings (Baumel 2005, 167-168). The Yiddish revival underway in Hasidic circles is thus resulting in first and second language acquisition among growing numbers of young Ultra Orthodox Jews.

[56] Montreal appears relatively immune to wider trends of Yiddish decline. It remains unique in the world in having almost twice as many native Yiddish speakers $(8,545)$ as Hebrew speakers $(4,320)$ (Lazarus 2008). Moreover, Werzberger suggests that the official figures for Yiddish use in the Montreal Hasidic community are far lower than the reality because of a reticence among respondents to answer "things the wrong way" to census takers; he claims that surveys conducted within the local community indicate as many as 15,000 native speakers, and projects numbers as high as 50,000 by 2030 : "we call it the revenge of the cradle—-that's our mother tongue" (Heinreich 2008). 


\section{Conclusions}

[57] The century-old "trope of Yiddish as moribund"-which has endured regardless of the actual state of the language— has in itself become a cultural phenomenon that triggers a variety of responses (Shandler 2006, 179). Discussion about the present and future of Yiddish has never been neutral: after all, a language only exists as a function of use (Hadda 2003). Contemporary Yiddishists promote Yiddish as a living language in groups such as Yugtnruf and on public forums such as the Mendele listserve (Yugntruf, Mendele). Janet Hadda identifies the above response as the denial stage in mourning the death of Yiddish (2006), and, along with writers such as Dara Horn, posits the transmission of the culture and spirit of Ashkenaz via "JudeoEnglish" in a new English-language literature (2006). Dovid Katz, himself the son of a Yiddish poet, posits that the "next major chapter in the unfinished story of Yiddish" lies with the Hasidim (2004). Heinrich's recent newspaper report on the current state of Yiddish in Canada offers the following provocative statement: "What the Hasidim have kept alive, other Jews have let wither away. For many, Yiddish has become a folkloric vestige of the waves of East European Jews who settled here generations ago and whose descendants long ago switched to English and French. Yiddish isn't completely dead, of course. But in mainstream society, it's becoming somewhat of a museum piece" (2008). What is "dying" are certain ways of experiencing and knowing the language and their carriers: the inevitable passing of a last generation of Europeanborn native Yiddish speakers, and, with them, the actualization of an ideology promoting Yiddish as a complete modern culture that was cut short by the rupture of the Holocaust and further dissolved by acculturation.

[58] Secular Canadian Yiddish culture in the post-Holocaust era can perhaps best be understood as in Shandler's model of horizontal succession, where it is transmitted through "cohort 
generations" rather than through the traditional "golden chain" of biological succession. Thus, rather than being passed down vertically from parent to child, Yiddish is being chosen in a "new, highly mobile, international cultural diaspora" that amounts to an open linguistic market (2006, 190-191). With few exceptions, Yiddish use today is deliberate and fragmented. Its locus is the classroom, festival stage or Yiddish gathering. Individuals who identify Yiddish not only as their mother tongue, but as a creative language and primary means of expressing Jewish identity are growing increasingly rare. The number of individuals who can pick up a Yiddish text, read it with ease and grasp all of the layers of meaning and nuance—outside of scholars—is dwindling. [59] Yiddish use and transmission underlines the growing polarization of Canadian Jewish life, with a widening gap between the Ultra Orthodox Hasidim and the rest of the Jewish community. The language is increasingly returning to its utilitarian roots as a means to an end, be it a connection to a lost past, a search for roots, a way to access historical research documents, or daily communication in an Orthodox community. In the case of the Hasidic communities, Yiddish has come full circle, back to its premodern origins as a linguistic carrier of Jewish tradition. Perhaps it has even come full circle in the realm of modern ideological struggles for continuity: as Glinert suggests, the Haredi promotion of Yiddish as a more "authentic" vernacular than English can be understood as akin to the efforts of nationalist Yiddishists a century ago to unify the masses $(1999,38)$.

[60] Elements of "postvernacular" Yiddish are increasingly evident in Canada. Across the country, Yiddish clubs and leynkrayzn (reading circles) are bringing together Yiddish speakers of various levels to engage with Yiddish through literature, song and conversation. ${ }^{13}$ Yiddish courses at community institutions such as synagogues or libraries teach elements of the language. The dominant function of this programming is not linguistic facility in Yiddish, but a means of 
expressing identity and values that include an attachment to Yiddish. These activities reflect the "performative nature of Yiddish culture," where the very act of using Yiddish carries meaning that outweighs the contents of what is actually said (Shandler 2004). Rather than a natural, spoken language, Yiddish has increasingly come to be perceived within the Jewish community as a mechanism for preservation and monumentalization of a vanishing or vanished culture. Yiddish use in the Canadian mainstream reflects the "atomization of Yiddish" (Shandler 2006, 156), with isolated Yiddish language terms — often vulgar or expressing intense emotionembedded in English. "Yinglish" usage in Canada includes terms such as drek (excrement, vulgar), narishkayt (silliness), tsuris (trouble), shmuck (jerk, vulgar, lit: male member), jutsper (khutspa, nerve) by non-Jewish news publications and politicians (Richler 2008). Within the Jewish community, fragments of Yiddish are employed to create and emphasize familiar ethnic connections. For example, Di gantseh Megillah: the Whole Story, an "online publication of features, opinions and Yiddishkeit" hosted by Montrealer Michael D. Fein, employs Yiddish terms to achieve a homey, comic effect: skullcap-wearing beagle "Howard the Yidishe Pup" presides over regular features such as "the Megillah Shmuck of the Month" (Gantse Megillah). As sociologist Morton Weinfeld posits in his survey of contemporary Canadian Jewish culture, “even as Yiddish shrinks as a language of daily use, it persists as a language that functions as a kind of Jewish code," blended with English to form a kind of "ethnolect" $(2001,38)$. Parallels exist between this concept of a hybridized Yiddishized English and "Yeshivish," a blend of Standard English with terms and expressions from Yiddish and loshn-koydesh employed as an insider vernacular within the Haredi community, in particular among Misnagdim ("opponents," originally to the emergence of Hasidism) (see Baumel 2003, Katz 2004, Weiser 1995). 
[61] The beginning of the twenty-first century marks a new threshold for engagement with Yiddish in Canada. Descendants of Yiddish-speaking immigrants commonly announce that their parents only spoke Yiddish "when they didn't want us to understand," but continue to nurture a symbolic connection with the language. Translators render the language and its wider cultural context for a popular readership. Performers draw on Yiddish to create new modes of expression and connection. Hasidim continue to actively speak Yiddish but not cultivate it. In short, Yiddish is as diversified as the Canadian Jewish community, and beyond. 


\section{References}

Abella, Irving Abella and Harold Troper. 1983. None is too many: Canada and the Jews of Europe, 1933-1948. New York: Random House.

Abley, Mark. 2004. Spoken Here: Travels among Threatened Languages. Toronto: Vintage Canada.

Ashkenaz Festival. Ashkenaz festival and foundation. http://www.ashkenazfestival.com. Retrieved June 21, 2008.

Baumel, Simeon. 2003. Black Hats and Holy Tongues: Language and Culture among British "Haredim.” European Judaism 36(2): 91-109.

. 2005. Sacred Speakers: Language and Culture among the Haredim in Israel. Oxford, New York: Berghahn Books.

Bagan, Ashley. 2008. "Students reclaim Yiddishist group. New Voices (February), http://newvoices.org/campus-news/students-reclaim-yiddishist-group.html. Retrieved June 21, 2008.

Belkin, Shimon. 1956. Di poyle-tsien bavegung in kanade, 1904-1920. Montreal: Northern Printing.

1999. Di poyle-tsien bavegung in kanade, 1904-1920/Le Mouvement ouvrier juif au Canada, 1904-1920. Trans. Pierre Anctil. Sillery, QC: Septendrion Press.

Bialik Hebrew Day School. Language. http://www.bialik.ca/schoolinfo.html?screen=academic\&section=languages. (Accessed June 21, 2008).

Butovsky, Mervin and Ode Garkinkle. 2007. “The journals of Yaacov Zipper, 1950-1982.” In Traduire le Montréal yiddish/New readings of Yiddish Montreal. Ed. Pierre Anctil, Norman Ravvin and Sherry Simon, 31-37. Ottawa: University of Ottawa Press.

Canadian Klezmer. http://www.canadianklezmer.bravehost.com. Accessed June 21, 2008.

Châteauvert, Julie and Francis Dupuis-Déri. 2004. Identités mosaïques. Entretiens sur l'identité culturelle des Québécois juifs. Montréal: Boréal.

Cohen, Nathan. 2002. "The Jews of Independent Poland: Linguistic and cultural changes." In Starting the twenty-first century: Sociological reflections \& challenges, ed. Ernest Krausz and Gitta Tulea, 161-75. New Brunswick, NJ: Transaction Publishers. . 2007. "The Yiddish press as distributor of literature." The Multiple Voices of Modern Yiddish Literature. Amsterdam Yiddish Symposium 2: 7-29.

Cohen, Steven M. 1993. "An Overview of the Canadian Jewish Community." In The Jews in Canada. Ed. Robert J. Brym et al., 39-57. Oxford: Oxford University Press.

. 2007. "Research, Insights and Challenges for Ottawa and Small-Medium North American Communities." Paper presented at the Building Ottawa's Jewish Future Symposium, February 15, in Ottawa, Canada.

Corcos, Arlette. 1997. Montréal, les juifs et l'école. Sillery: Éditions du Septendrion. 
Davids, Leo. 1993. "Yiddish in Canada: Picture and Prospects." In The Jews in Canada. Ed. Robert J. Brym, William Shaffir and Mortin Weinfeld, 153-166. Don Mills: Oxford University Press.

Deshaies, D. et al. 1997. "Immunization against Hepatitis A during an Outbreak in a Jewish Community-Quebec 1997-1998." Canadian Communicable Disease Report 24(18), Health Canada. http://www.phac-aspc.gc.ca/publicat/ccdr-rmtc/98vol24/dr2418ea.html. Accessed June 21, 2008.

Dora Wasserman Yiddish Theatre. http://www.saidyebronfman.org/yiddish/yit_home.html. Accessed June 21, 2008.

Estraikh, Gennady. 1999. Soviet Yiddish: Language-planning and Linguistic Development. Oxford: Clarendon Press. . 2005. In Harness: Jewish Yiddish Writers' Romance with Communism. Syracuse: Syracuse University Press.

Feldman, Walter Zev. 2002. "Bulgărească/Bulgarish/Bulgar: The Transformation of a Klezmer Dance Genre." In American Klezmer: Its Roots and Offshoots. Ed. Mark Slobin, 86126. Berkeley: University of California Press.

Felsen, Vivian. 2007. “Translating Israel Medres." In Traduire le Montréal yiddish/ New readings of Yiddish Montreal, ed. Pierre Anctil, Norman Ravvin and Sherry Simon, 11015. Ottawa, University of Ottawa Press.

Fishman, David. 2005. The Rise of Modern Yiddish Culture. Pittsburgh: University Of Pittsburgh Press.

Fishman, Joshua A. 1981. "Attracting a Following to High-Culture Functions for a Language of Everyday Life: The Role of the Tshernovits Language Conference in the 'Rise of Yiddish."' In Never Say Die!: A Thousand Years of Yiddish in Jewish Life and Letters. Ed. Joshua A. Fishman, 369-394. The Hague, Paris and New York: Mouton.

Forman, Frieda, et al. eds. 1994. Found Treasures: Stories by Yiddish Women Writers. Toronto: Second Story Press.

Fuerstenberg, Adam G. 1984. "From Yiddish to 'Yiddishkeit': A.M. Klein, J.I. Segal and Montreal's Yiddish Culture." Journal of Canadian Studies 19: 66-81.

Gantse Megillah. www.gantsehmegillah.com. Accessed June 21, 2008.

Giberovitch, Myra. 1994. "The Contributions of Holocaust Survivors to Montreal Jewish Communal Life." Canadian Ethnic Studies 25(1): 74-86.

Glinert, Lewis H. 1999. "We Never Changed our Language: Attitudes to Yiddish Acquisition among Hasidic Educators in Britain." International Journal of the Sociology of Language 138: $31-52$.

Goldberg, Ben Zion. 1955. "In gang fun tog: ayndrukn—montreol.” Tog-morgn zhurnal. April 19.

Goldsmith, Emanuel S. 1987. Modern Yiddish Culture: The Story of The Yiddish Language Movement. New York: Shapolsky Publishers. 
Gutkin, Harry. 1980. Journey into our Heritage: The Story of the Jewish People in ihe Canadian West. Toronto: Lester \& Orpen Dennys.

Hadda, Janet. 2003. "Imagining Yiddish: A Future for the Soul of Ashkenaz." Pakntreger Spring: 10-19. . 2006. "Transmitting Ashkenaz." Shofar 25(1): 114-126.

Harris, Eiran. 2006. "Yiddish was official in Quebec." Outlook (May/June): 12.

Harshav. Benjamin. 1990. The Meaning of Yiddish. Berkeley: University of California Press.

Hatzolah Kyrias Tosh. http://hatzolah.com (Accessed June 22, 2008).

Heinreich, Jeff. 2008. "Language of past sets Hasidim apart today." Montreal Gazette. February 23.

Hill, Brad Sabin. 2006. "Early Hebrew Printing in Canada." Studia Rosenthaliana 38(9): 30647.

Horn, Dara. 2006. "The Future of Yiddish-In English: Field Notes from the New Ashkenaz." Jewish Quarterly Review 96(4): 471-80.

Isaacs, Miriam. 1999. "Haredi, haymish and frim: Yiddish Vitality and Language Choice in a Transnational, Multilingual Community." International Journal of the Sociology of Language 138: 9-30.

JPPS Elementary School. Languages. http://www.jppsbialik.ca/en/jpps/academics/languages. (Accessed June 22, 2008).

Jacobs, Neil G. 2005. Yiddish: A Linguistic Introduction. Cambridge?New York: Cambridge University Press.

Joe Fishstein Collection of Yiddish Poetry. "A Garment Worker's Legacy." http://digital.library.mcgill.ca/fishstein. Accessed June 22, 2008.

Jones, Faith. 1999. The Vancouver Peretz Institute Yiddish Library: The Social History of a Jewish Community Library." MA Thesis, University of British Columbia. . 2006. "A Chimney on the Canadian Prairies: Yiddish-Language Libraries in Western Canada, 1900 to the Present." Judaica Librarianship 12: 49-68.

Katz, Dovid. 1987. Grammar of the Yiddish Language. London: Duckworth 2004. Words On Fire: The Unfinished Story of Yiddish. New York: Basic Books.

Kellman, Ellen. 2003. "Dos yidishe bukh alarmirt! Towards the History of Yiddish Reading in Interwar Poland." Polin 16: 213-41.

Kerler, Dov-Ber. 1999. The Origins of Modern Literary Yiddish. Oxford: Clarendon Press.

Kirshenblatt-Gimblett, Barbara. 2002. "Sounds of sensibility." In American Klezmer: Its Roots and Offshoots. Ed. Mark Slobin, 129-173. Berkeley: University of California Press.

Kiryas Tash. http://www.kiryastash.ca/index.shtml. Accessed June 22, 2008.

Klezkanada, http://www.klezkanada.com/site/. Accessed June 22, 2008.

Klezmer Shack. http://www.klezmershack.com. Accessed June 22, 2008.

Journal of Religion and Popular Culture

Volume 21: Special Edition - Religion and Popular Culture in Canada (2009) 
Krutikov, Mikhail. 2002. "Reading Yiddish in a Post-Modern Age: Some Trends in Literary Scholarship of the 1990s." Shofar 20(3): 1-13.

Lampert, Allison. 2003. "Mohawks see selves in ghetto drama." Montreal Gazette. September 17.

Lansky, Aaron. 2004. Outwitting History: The Amazing Adventures of a Man Who Rescued a Million Yiddish Books. Chapel Hill: Algonquin Books of Chapel Hill.

Lapidus, Steven. 2004. "The Forgotten Hasidim: Rabbis and Rebbes in Prewar Canada." Canadian Jewish Studies 12: 1-30.

. 2007. "Canadian Highlights: A Hasidic Magazine Made in Canada." Paper presented at A Celebration of Jewish Studies in Ottawa Conference, October 24-25, Ottawa, Canada.

Larrue, Jean-Marc. 1996. Le théâtre yiddish à Montréal/Yiddish Theatre in Montreal. Montreal: Éditions Jeu.

Lazarus, David. 2008. "Yiddish speakers drop by 10,000 in five years." Canadian Jewish News, February 21.

Levy, Daniel C. 1987. "Jewish Education in Latin America." In The Jewish Presence in Latin America. Ed. Judith Laikin Elkin and Gilbert W. Merkx, 157-84. Winchester: Allen and Unwin.

Margolis, Rebecca. 2007. "Sholem Shtern: Bridging the Gaps." In Traduire le Montréal yiddish/ New Readings of Yiddish Montreal. Ed. Pierre Anctil, Norman Ravvin and Sherry Simon, 93-102. Ottawa: University of Ottawa Press. . 2008. "Yiddish Translation in Canada: A Litmus Test for Continuity." Traduction Terminologie Rédaction 19(2): 149-89.

. 2009. "Negotiating Jewish Canadian Identity: Montreal Yiddish Literary Journals in the Interwar Period." Shofar 27 (4). Forthcoming.

Mendele: Forum for Yiddish Literature and Yiddish Language. http://www2.trincoll.edu/ mendele. (Accessed June 22, 2008).

Michels, Tony. 2000. "Speaking To Moyshe: The Early Socialist Press and its Readers." Jewish History 14(1): 51-82.

. 2005. A Fire in Their Hearts: Yiddish Socialists in New York. Boston: Harvard University Press.

Mintz, Alan. 1995. "The Many Rather than the One: On the Critical Study of Jewish Periodicals." Prooftexts 15 (1995): 1-4.

Modern Languages Association. Enrolments in languages other than English in United States institutions of higher education, Fall 2006. Web publication 13 November 2007. http://www.mla.org. (Accessed June 22, 2008).

Morgentaler, Goldie. 2007. "Yiddish Montreal Lost And Regained: The Recuperative Power Of The Translated Word." In Traduire le Montréal yiddish/ New Readings of Yiddish 
Montreal. Ed. Pierre Anctil, Norman Ravvin and Sherry Simon, 103-109. Ottawa: University of Ottawa Press.

National Yiddish Book Center. http://www.yiddishbookcenter.org. Accessed June 22, 2008.

Nepveu, Pierre. 2007. “Traduit du yiddish: échos d'une langue inconnue.” In Traduire le Montréal yiddish/ New Readings of Yiddish Montreal. Ed. Pierre Anctil, Norman Ravvin and Sherry Simon, 72-76. Ottawa: University of Ottawa Press.

Niger, Sh. 1954. “Gut morgn dir, velt!” Tog-morgn zhurnal. March 7.

Norich, Anita. 2007. Discovering Exile: Yiddish and Jewish American Culture during the Holocaust. Stanford: Stanford University Press.

“On Foreign Soil, What's it all about?" http://www.onforeignsoil.com/summary.htm. Accessed June 22, 2008.

Orenstein, Eugene. 1981. "Yiddish Culture in Canada Yesterday and Today." In The Canadian Cultural Mosaic. Ed. M. Weinfeld, W. Shaffir and I. Cotler, 293-314. Rexdale, ON: John Wiley and Sons.

Outlook, Canada's Progressive Jewish Magazine. http://www.vcn.bc.ca/outlook. Accessed June 22, 2008.

Parker, Sandra. 1981. "An Educational Assessment of the Yiddish Secular School Movements in the United States." In Never Say Die!: A Thousand Years of Yiddish in Jewish Life and Letters. Ed. Joshua A. Fishman, 495-512. The Hague/Paris/New York: Mouton.

Peretz Centre for Secular Jewish Culture. http://www.peretz-centre.org/index.html. Accessed June 22, 2008.

Pomson, Alex and Randal F. Schnoor. 2008. Back to School: Jewish Day School in the Lives of Adult Jews. Detroit: Wayne State University Press.

Prager, Leonard. 1981. "Yiddish in the University." In Never Say Die!: A Thousand Years Of Yiddish in Jewish Life and Letters. Ed. Joshua A. Fishman, 529-550. The Hague/Paris/ New York: Mouton.

Raby, Eva. 2004. "Memories of Yiddish Montreal." In Traduire le Montréal yiddish/ New Readings of Yiddish Montreal. Ed. Pierre Anctil, Norman Ravvin and Sherry Simon, 5761. Ottawa: University of Ottawa Press.

Ravitch, Melekh. 1963. "Yiddish Culture in Canada." In Canadian Jewish Reference Book and Directory, 75-80. Ottawa: Mortimer Limited.

Richler, Howard. 2008. "Nu? Aren't there enough Yiddishisms already?" Canadian Jewish News. January 3. Perspectives.

Robinson, Ira. 2007. Rabbis and their Community: Studies in the Eastern European Orthodox Rabbinate in Montreal, 1896-1930. Calgary: University of Calgary Press, 2007.

Louis Rosenberg, Canada's Jews-A Social and Economic Study of the Jews in Canada. Montreal: Canadian Jewish Congress, 1939. Reissued as: Canada's Jews: A Social and Economic Study of the Jews in Canada in the 1930s. Ed. Morton Weinberg. Montreal/Kingston/London/ Buffalo: McGill-Queen's University 
Press, 1993.

Rosenberg, Michael and Jack Jedwab. 1992. "Institutional Completeness, Ethnic Organizational Style and the Role of the State: The Jewish, Italian and Greek Communities of Montreal." The Canadian Review of Sociology and Anthropology 29(3): 266-87.

Rosenfarb, Chava. 2004. "Canadian Yiddish Writers." In Traduire le Montréal yiddish/ New Readings of Yiddish Montreal. Ed. Pierre Anctil, Norman Ravvin and Sherry Simon, 1118. Ottawa: University of Ottawa Press.

Roskies, David G. 1990. "Yiddish in Montreal: The Utopian Experiment.” In An Everyday Miracle: Yiddish Culture in Montreal. Ed. Ira Robinson, Pierre Anctil and Mervin Butovsky, 22-38. Montreal: Véhicule Press.

Royzenblat, Rivke. 1929. Lider. New York: Y.L. Magid.

Sandrow, Nehma. 1996. Vagabond Stars: A World History of Yiddish Theatre. Syracuse, NY: Syracuse University Press.

Schwartzberg, Shlomo. 2008. "Vol. 2 of Simchovitch's Yiddish-English Collection Published." Canadian Jewish News, June 22.

Segal, J.I. 1929. "Akshones (Stubborness)." In Folksshuln bukh: tsum 15-yorikn yubileyum, 45-47. Montreal: Yidishe Folkshuln.

Shaffir, William. 1974. Life in a Religious Community: The Lubavitcher Chassidim in Montreal. Toronto: Holt, Rinehart and Winston.

. 1995. "Safeguarding a Distinctive Identity: Hassidic Jews in Montreal." In Renewing Our Days: Montreal Jews in the Twentieth Century. Ed. Ira Robinson and Mervin Butovsky, 74-94. Montreal: Véhicule Press.

Shandler, Jeffrey. 2000. "Beyond the Mother-Tongue: Learning the Meaning of Yiddish in America." Jewish Social Studies 6(3): 97-123.

. 2003. "Imagining Yiddishland: Language, Place and Memory." History \& Memory 15(1): 123-149. . 2004. "Postvernacular Yiddish: Language as a Performance Art." TDR: The Drama

Review 48(1): 19-43.

. Adventures in Yiddishland: Postvernacular Language and Culture. Berkeley:

University of California Press, 2006.

Shneer, David. 2004. "Who Owns the Means of Cultural Production? The Soviet Yiddish Publishing Industry of the 1920s." Book History 6: 197-226.

Simon, Sherry. 2007. "Translating Montreal: Episodes in the Life of a Divided City." Montreal: McGill-Queen's University Press.

Slobin, Mark. 1984. "Klezmer music: An American Ethnic Genre.” Yearbook for traditional music 16: 34-41. . 2000. Fiddler on the Move: Exploring the Klezmer World. Oxford: Oxford University Press. 
Speisman, Stephen. 1979. The Jews of Toronto: A History to 1937. Toronto: McClelland and Stewart.

Statistics Canada. 2006 Census. http://www12.statcan.ca/english/census/index.cfm. (Accessed June 22, 2008).

Stein, Sarah Abrevaya. 2004. Making Jews Modern: The Yiddish and Ladino press in the Russian and Ottoman Empires. Bloomington: Indiana UP. . 2006. "Asymmetric Fates: Secular Yiddish and Ladino Culture in Comparison." Jewish Quarterly Review 96(4): 498-509.

Steinlauf, Michael C. 2003. "Jewish Theatre in Poland." Polin 16L 71-91.

Tregebov, Rhea, ed. (2007). Arguing with the Storm: Stories by Yiddish Women Writers. Vancouver: Sumach Press.

Tulchinsky, Gerald. 1984. “The Third Solitude: A. M. Klein's Jewish Montreal, 1910-1950.” Journal of Canadian Studies 19: 96-112.

. 1992. Taking Root: The Origins of the Canadian Jewish Community. Toronto: Lester Publishing.

UJPO (United Jewish People's Order). Winchevsky Centre. http://www.winchevskycentre.org/institutions/ujpo.html. (Accessed June 22, 2008).

Usiskin, Roz. 1977. "The Winnipeg Jewish Community: Its Radical Elements, 1905-1918." MHS Transactions 3(33). http://www.mhs.mb.ca/docs/transactions/3/jewishradicals.shtml (Accessed June 20, 2008).

Victor, D.I. 2002. "Radical Jewish Education in Winnipeg." In Jewish Radicalism in Winnipeg, 1905-1960. Ed. Daniel Stone. Winnipeg: Jewish Heritage Centre of Western Canada.

Virtual Shtetl. Shtetl: Yiddish Language and Culture, School. http://www.ibiblio.org/yiddish. (Accessed June 22, 2008).

Warnke, Nina. 2004. "Going East: The Impact of American Yiddish Plays and Players on the Yiddish Stage in Czarist Russia, 1890-1914.” American Jewish history 92(1): 1-29.

Weinfeld, Morton. 2001. Like everyone Else...but different: The Paradoxical Success of Canadian Jews. Toronto: McClelland and Stewart.

Weinreich, Max. 1970. History of the Yiddish Language. Chicago: University of Chicago Press.

Weiser, Chaim M. 1995. Frumspeak: The Dictionary of Yeshivish. Northvale: Jason Aronson.

Wex, Michael. 2005. Born to Kvetch: Yiddish Language and Culture in all Its Moods. New York: Martin's Press. . 2007. Just Say Nu: Yiddish for Every Occasion (When English Just Won't Do). New York: St. Martin's Press.

Wiseman, Shloime. 1982. "A memuar fun mayn lebn vi a yidisher dertsyer (A memoir of my life as a Yiddish educator)." In Kanader yidisher zamlbukh/Canadian Jewish 
anthology/Anthologie juive du Canada. Ed. Chaim Spilberg, Yaacov Zipper, 380-414. Montreal: Canadian Jewish Congress.

The Yiddish World of Michael Wex. http://www.the-yiddish-world-of-michaelwex.com/index.html. (Accessed June 22, 2008).

Yugntruf. Youth for Yiddish. http://www.yugntruf.org. (Accessed June 22, 2008).

Zolf, Falk. 2000. On Foreign Soil. Trans. Martin Green. Winnipeg: Benchmark Publishing.

\section{Notes}

${ }^{1}$ The term "Hasid" (also in Hasidic, Hasidim) is also spelled Hassid, Chasid, or Chassid.

${ }^{2}$ Ashkenazim are Jews of Germanic descent whose civilization spread to Central and Eastern Europe.

${ }^{3}$ Sephardim are Jews with roots in the Iberian Peninsula whose civilization spread to Southeastern Europe.

${ }^{4}$ The term "yiddishkayt," alternately rendered yidishkayt or yiddishkeit, refers to the full scope Ashkenaz civilization or culture, and/or its heritage.

${ }^{5}$ The Canadian census defines mother tongue as the language first learned in childhood and still understood.

${ }^{6}$ According to the estimates of the American Jewish Yearbook of 1913-1914, the total Jewish population of the United States in 1910 was 2,043,762 and the number of Jews declaring Yiddish as mother tongue was $990,587(423,428)$.

${ }^{7}$ Unless otherwise indicated, all translations from the Yiddish are mine.

${ }^{8}$ Rubin's pioneering efforts at collecting Yiddish folksong produced the seminal collection, Voices of a People (1973).

${ }^{9}$ The English translation, "committee" is misleading. As Yiddish linguist Mordkhe Schaechter has pointed out, a komitet indicates an informal and temporary structure. See "Laytish mame loshn," Afn shvel 321 (Jan.-Mar. 2000), 19.

${ }^{10}$ Between 2001 and 2008, the NYBC sold estimated 17,000 used Yiddish books and reprints were sold, and provided another 4,000 pro bono. Catherine Madsen, National Yiddish Book Center, e-mail message to author, February 14, 2008.

11 The term "klezmer" means "musical instrument" in the original Hebrew, and came to refer to a musician in Yiddish (plural: klezmorim); today, it is used as the name of a genre of Jewish music.

${ }^{12}$ A Québec dialect of French.

${ }^{13}$ Five of these groups are listed on the website of Der Bay: the International Anglo-Yiddish Newsletter as members of the International Association of Yiddish Clubs: http://www.derbay.org/clubs.html. 